\title{
A world shared - a world apart: The experience of families after the death of a significant other late in life
}

DOI:

10.1111/jan. 13107

\section{Document Version}

Accepted author manuscript

Link to publication record in Manchester Research Explorer

\section{Citation for published version (APA):}

Naef, R., Ward, R., Mahrer-Imhof, R., \& Grande, G. (2016). A world shared - a world apart: The experience of families after the death of a significant other late in life. Journal of Advanced Nursing, 73(1), 149-161.

https://doi.org/10.1111/jan.13107

\section{Published in:}

Journal of Advanced Nursing

\section{Citing this paper}

Please note that where the full-text provided on Manchester Research Explorer is the Author Accepted Manuscript or Proof version this may differ from the final Published version. If citing, it is advised that you check and use the publisher's definitive version.

\section{General rights}

Copyright and moral rights for the publications made accessible in the Research Explorer are retained by the authors and/or other copyright owners and it is a condition of accessing publications that users recognise and abide by the legal requirements associated with these rights.

\section{Takedown policy}

If you believe that this document breaches copyright please refer to the University of Manchester's Takedown Procedures [http://man.ac.uk/04Y6Bo] or contact uml.scholarlycommunications@manchester.ac.uk providing relevant details, so we can investigate your claim.

\section{OPEN ACCESS}




\section{AN}

Informing Practice and Policy Worldwide

through Research and Scholarship

\section{A world shared - a world apart: The experience of families after the death of a significant other late in life}

\begin{tabular}{|r|l|}
\hline Journal: & Journal of Advanced Nursing \\
\hline Manuscript ID & JAN-2016-0258.R1 \\
\hline Manuscript Type: & Original Research: Empirical research - qualitative \\
\hline Keywords: & $\begin{array}{l}\text { Family care, Bereavement, Older People, Phenomenology, Carers, } \\
\text { Hermeneutics }\end{array}$ \\
\hline Category: & Nursing \\
\hline \multicolumn{2}{|c}{} \\
\hline
\end{tabular}

SCHOLARONE

Manuscripts 
Revision Protocol - Manuscript ID JAN-2016-0258

\section{A world shared - a world apart: The experience of families after the death of a significant other late in life.}

\section{Editing}

\begin{tabular}{|l|l|}
\hline Ediotorial comment & Comment \\
\hline $\begin{array}{l}\text { Format of headings: main headings UPPER } \\
\text { CASE, major sub-headings lower case, } \\
\text { subsidiary sub-headings italics. }\end{array}$ & $\begin{array}{l}\text { Headings have been re-formatted to fit with the } \\
\text { JAN guideline }\end{array}$ \\
\hline Word count 5000 words & Reduced from 5331 to 5262 \\
\hline $\begin{array}{l}\text { For Research papers, provide the inclusive } \\
\text { years of data collection in both the abstract and } \\
\text { the text. }\end{array}$ & $\begin{array}{l}\text { Year of data collection included in abstract. No } \\
\text { changes in the text since the date was already } \\
\text { given under "sample / participants" }\end{array}$ \\
\hline
\end{tabular}

\section{Reviewer 1}

\begin{tabular}{l}
\hline Reviewer comment \\
Because it was long winded at times, the \\
summary after the abstract should be made \\
clearer and possibly highlighted. \\
\hline My major difficulty is in not knowing enough \\
about the families. What were their incomes and \\
what were their belief structures, do they attend \\
church, what was there social standing etc. \\
Most of the missing data could easily be added \\
to table I.
\end{tabular}

Also were they chosen to be homogeneous or to be different or was it random.

\section{Comment}

The summary statement was shortened and fully revised to make it more concise.

The only data collected on social standing was years of education and self-perceived financial situation. In addition to years of education, selfperceived ability to manage with monthly income has been inserted in table 1

No data was collected on belief structure.

Sampling was purposive guided by inclusion / exclusion criteria. The actual homogeneity of the sample occurred at random (but was probably due to the fact that most often, home care nurses created access to families). The heterogeneity / homogeneity of the sample were of concern in making decisions about the sample size (i.e. when the sample would have been heterogeneous, more cases might have been necessary. Thus, the sentence addressing decision-making about sample size has been slightly reworded (under "sample / participants")

I am not sure if the family names are blinded, if not was permission sought to use the real names.

The last sentence under "ethical considerations" reads: "To ensure anonymity, code names were used". In the authors' view, this states clearly that no real names were used. A footnote has been added in table 2 that states that the names given in the table are code names.

I notice some families were chosen by ministers and some by nurses was there a difference between them?
Only two families were recruited by ministers, one self-referred and 7 were recruited by nurses. The researchers noted no discernable difference between families based on recruitment process. Given the length restrictions of the paper, the sentence was simplified. 
After the quotes there is a reference given but no explanation as to what it referred to or where the reference could be viewed, or for how long it would be available.
Reference indicates the document and line numbers of the interview transcripts. They can only be accessed via the researcher. Hence, references have been deleted (also out of considerations about word length), and only the participant names (either individual family member, family name or both) are now given since this can be checked with table 2 .

\section{Reviewer 2}

\begin{tabular}{|l|l|}
\hline Reviewer comment & Comment \\
\hline p.4 line 34 should say 'grieving' and not 'grief' & corrected \\
\hline p.5 line 30 ( $\geq 18$ years) not needed & deleted \\
\hline p.5 line 42 unstructured not 'open' & changed \\
\hline p.5 line 50 understood not understand & corrected \\
\hline $\begin{array}{l}\text { p.7 Findings - perhaps a mention of sub- } \\
\text { themes should be made as these are evident } \\
\text { within the themes. }\end{array}$ & $\begin{array}{l}\text { Yes indeed, sub-headings are equal to the } \\
\text { discerned family practices related to meaning- } \\
\text { making of the death, living with the loss, and } \\
\text { family life in the wake of loss. To clarify this point, } \\
\text { a table was created that provides a succinct } \\
\text { overview (table 3) }\end{array}$ \\
\hline $\begin{array}{l}\text { p. } 8 \text { and onwards... Quotes in text are given in } \\
\text { Italics but not when free standing, why? It } \\
\text { seems inconsistent. }\end{array}$ & $\begin{array}{l}\text { In-text quotes have been reformatted according } \\
\text { to the guideline given on the JAN website (no } \\
\text { italics for quotations) }\end{array}$ \\
\hline $\begin{array}{l}\text { p.15 line } 56 \text { Tenuous statement, which I think } \\
\text { needs to be elaborated on. }\end{array}$ & Statement was reworded and further clarified. \\
\hline p.16 line 13 voices not 'voice & corrected \\
\hline $\begin{array}{l}\text { p.16 line 22, the last sentence is not clear. This } \\
\text { is about bracketing, but difficult to understand } \\
\text { the point that is made. }\end{array}$ & Reworded to clarify the point. \\
\hline
\end{tabular}




\section{Abstract}

Aims: To investigate the impact of the death of an older member on families.

Background: The death of a significant other in later life is a dramatic moment. Research has demonstrated that some older persons face negative consequences for their well-being. A majority, however, exhibits resilience in the wake of loss. Nonetheless, the relational process through which older persons come to terms with the loss in interaction with their families is little understood, but vital to support bereaved families.

Design: Heideggerian hermeneutic phenomenology.

Methods: A purposive sample of ten older persons with their families, represented by children, grandchildren and in-laws $(n=30)$ were interviewed several times in 2013, alone $(n=16)$ and in family groups $(n=21)$, six to 23 months after their significant other's death (mean age 81y). Data collection and thematic analysis was informed by van Manen's and Benner's analytical strategies.

Findings: Three family themes were discerned. First, through meaning-making, bereaved families weaved the death into their family narrative. Second, through sharing-not sharing their feelings and daily moments, family members lived with the loss both together and alone. Third, some families faced upheaval in their family life, which required them to re-create their everyday life, whereas other families continued with little change.

Conclusions: Findings demonstrate that families hold an inherent capacity to make meaning of the death and enact family thereafter. Family relations arose as interplay of different, contradicting forces. Nurses should facilitate families' meaning-making of the death, attend to their converging and diverging sense of loss, and strengthen family caring. 


\section{SUMMARY STATEMENT}

\section{Why is this research or review needed?}

- To date, grief has predominantly been studied as an intrapersonal process from the perspective of bereaved older spouses and carers.

- Families' situation following a loss late in life remains poorly understood.

- To provide meaningful and relevant bereavement care across settings, nurses require an in-depth understanding of families' relational loss experience.

\section{What are the key findings?}

- Findings revealed that death happens to "a family", but affects members and generations in unique ways.

- Families collectively integrate shared meanings into their family narrative, enact community through connecting in daily life, and move together as they transition into their new family situation without the deceased.

- Concurrently, families' life with loss unfolds in diverging ways for individual members, and involves disconnection during moments in which family members did not want to, or could not share.

\section{How should the findings be used to influence policy/practice/research/education?}

- Family nursing interventions should enable families' meaning-making and aim to strengthen their relational and caring capacities in bereavement while also attending to individual, diverging experiences and needs.

- Relationship-focused, health-promoting approaches to care should be used when working with bereaved persons and families in later life.

- Research should further explore family needs and health outcomes in bereavement.

Keywords: Family care, family relations, older person, bereavement, phenomenology, hermeneutics 


\section{INTRODUCTION}

Most persons die late in life after a persistent illness for which they received family care (Schulz et al. 2001, Hudson 2013). Although the loss of siblings and friends is most frequent among the very old, the death of a significant other affects older persons in intimate ways (Lalive d'Epinay et al. 2009). It not only ends a long-standing relationship, but uproots personal identities, social roles, and established daily activities (Carr et al. 2006, Moss \& Moss 2014). Conjugally bereaved older persons face difficult emotions and a pervasive sense of loneliness despite busy lives (Naef et al. 2013), which may have negative consequences for their well-being (Thomas et al. 2014). Notwithstanding these manifold challenges, most are able to cope with their bereavement situation over time, and only a smaller proportion experience debilitating forms of grief (Bonanno et al. 2002, Ott \& Lueger 2002, Spahni et al. 2015). It is well established that social networks are an important source of support (Brazil et al. 2003, Naef et al. 2013, Powers et al. 2014). For older bereaved persons, adult children play a pivotal role in providing emotional and instrumental support (Ha 2008, Ha \& Ingersoll-Dayton 2008). Hence, a consensus has evolved that most come to terms with their grief in interaction with their families and friends (National Institute for Clinical Excellence 2004, Rumbold \& Aoun 2014). However, the relational process by which a group of interconnected people experiences a change in relationships through death remains poorly understood (Hayslip \& Page 2013, Thirsk \& Moules 2013).

\section{Background}

Most insights about later life bereavement are based on research with individuals. Hence, grief has predominately been recognized as an intrapersonal process and only to a lesser extent as an interpersonal experience (Hayslip \& Page 2013, Neimeyer et al. 2014). However, a small body of research with adult bereaved families has demonstrated that family system characteristics impact on individuals' experience of grief. Individuals within families with low to some cohesiveness and moderate to high conflict were found to experience more intense grief and to be at greatest risk for depression compared to individuals of families who felt close and had no conflicts (Kissane et al. 1996a, Kissane et al. 1996b, Kissane et al. 
1997, Traylor et al. 2003). It has also been found that bereaved families engage in an interactive, collective process of finding meaning in light of their family identity, rules, and beliefs (Nadeau 1998, Black \& Santanello 2012, Black et al. 2014).

Theoretical writings most often posit family as a relational context to individuals' lives, whereby families are seen as a source of support (Gilbert 1996, Shapiro 2001). Moreover, family system perspectives recognize family as more and different from individuals merely interacting with each other (Nadeau 2001, Hayslip \& Page 2013). As such, the death of a family member is a system-wide event that disrupts families in their particular situation and context (Berger \& Weiss 2009, Hayslip \& Page 2013). Bereaved families' unique configurations, needs, capacities, and meaning-making strategies are of interest (Berger and Weiss, 2009; Davis et al., 2012; Gilbert, 2007; Nadeau, 2008). While a focus on what constitutes age-normative family functions continues to abound, it is increasingly appreciated that manifold ways of living as a family and grieving meaningfully co-exist (Hedtke \& Winslade 2004, Nadeau 2008, Neimeyer 2012, Thirsk \& Moules 2012).

\title{
THE STUDY
}

\author{
Aim \\ The aim of this study was to investigate families' bereavement experience after an \\ older person's significant other has died. \\ Design \\ Hermeneutic phenomenology informed the study design (Heidegger 1926/2001, \\ Gadamer 1975/1989). Based on the premise that understandings and actions are inter- \\ subjective, and arise from a particular world shared with others (Heidegger 1926/2001), \\ families' practical involvement with their world and the meanings they gain were the focus of \\ this inquiry (Plager 1994, Chesla 1995). Within hermeneutics, the linguistic nature of \\ understanding gives rise to the possibility to gather families' accounts through dialogue \\ (Gadamer 1975/1989, van Manen 1990). To seek understanding, hermeneutic researchers \\ depart from their own being-in-the-world, in this case from that of a nurse researcher, \\ spouse, mother and daughter, who has witnessed dying in her clinical practice and in her
}


oldest family generation. An interpretation is sought through an abiding engagement with the text and a hermeneutic spiralling process (Benner 1994, Spichiger \& Prakke 2003, Smith 2007). Interpretive efforts attempt to gain insights through explicating fore-understandings as they evolved in relation to the phenomenon under study and the emerging textual interpretation (Gadamer 1975/1989, Geanellos 1998a).

\section{Sample / Participants}

Older persons ( $\geq 75$ years) whose significant other had died within the two previous years of various causes, together with their families, were purposively selected and recruited from an urban area in (country) between November 2012 and October 2013, predominantly by home care nurses who had provided care to the deceased. At least one additional family member or someone close was recruited through the bereaved spouse. Exclusion criteria were institutionalization, cognitive incapacity to take part in the study, or serious mental illness. Decisions about sample size were guided by considerations around the homogeneity of the sample, the completeness of each family case, and the redundancy of the gathered data (Benner 1994).

\section{Data collection}

Twenty-one family and 16 individual unstructured, face-to-face interviews were carried out by the first author six to 23 months after the death. Family interviews aimed to learn about family interpretations and practices with loss and set up a context to speak as naturally as possible (Benner 1994, Bell et al. 2000, Taylor \& de Vocht 2011). Individual interviews sought to discern how individuals understood family processes and to better comprehend individual meanings and actions. Several interviews were held with each family over a time period ranging between ten to 23 weeks. The first interview began with an invitation to families to talk about the death and to portray their close other. A family genogram was drawn to understand family configurations (Rempel et al. 2007). The researcher invited participants to discuss what had happened since the death, and how they experience life without their significant other. Follow-up interviews served to further explore and complement families' and individuals' stories and descriptions. Field-notes were written 
and included observations of the interview, reflections on the researcher's role and on participants' descriptions. Demographic information was collected with a short questionnaire. Interviews were held in (language). Data were transcribed verbatim, and anonymized transcripts entered into Atlas.ti version 7 for data management purposes.

\section{Ethical considerations}

The study was approved by the (name) Ethics Committee and the University (name) Research Ethics Committee. Each family member was contacted to obtain oral consent before the first interview, upon which each signed a written informed consent. Family members had the opportunity to renew or withdraw consent at any point of contact (Rosenblatt 1995). Families made decisions about the number, type and order of the interviews. Although they experienced painful moments during the interviews, no situation of emotional distress occurred that required further care. To ensure anonymity, code names were used.

\section{Data analysis}

To discern family meanings and actions, thematic analysis was conducted, which unfolded through a recurring process of reading and writing, developing interpretive questions and refining emerging lines of inquiry through moving between parts and the whole of the text (van Manen 1990, Benner 1994). Analysis commenced with single interviews, then moved back and forth between family cases and the whole data set, asking questions such as: "What is the main twist of the story told by each member and family?", "What is a description about, and why is it told in the way it is?" Initial thematic lines of inquiry were formulated from across cases by asking "How do thematic ideas arise across families?", "How is it the same or different for each family?", "Is there a family whose experiences, actions or concerns stand out as paradigmatic, i.e. illustrate thematic threads particularly well?", and substantiated by re-engaging with thematically organized text or particular cases until no new insights could be derived.

\section{Rigour}


The four validity criteria by Whittemore et al. (2001) were applied to this study. Credibility and authenticity were sought through a prolonged and repeated engagement with participants through multiple interviews that generated rich textual data, which has likely achieved completeness and redundancy in relation to the research question (Smith et al. 2009). To ensure criticality and integrity, the researcher explicated fore-understandings and engaged in ongoing critical reflection to render visible the imprints on the study (Geanellos 1998a, Geanellos 1998b). Regular interpretive team meetings were held, and analytical decisions were kept in a research log. Representative sections of transcripts were translated into English to facilitate joint interpretation (Santos et al. 2015).

\section{FINDINGS}

Participant characteristics are displayed in table one, and individual family cases in table two. Ten widow/ers ( $80 \pm 4$ years) and their families, represented by adult children $(n=14 ; 51 \pm 5 y)$, grand-children $(n=3 ; 20 \pm 4 y)$, and in-laws $(n=3 ; 77 \pm 4 y)$ took part in 37 interviews lasting on average $82(15-129)$ minutes, most often in their homes $(n=30)$. All participants were of $x x$ (country) origin.

Interviews revealed three family themes (table 3). First, bereaved families weaved the death into their family narrative. Second, through sharing-not sharing their feelings and daily moments, family members lived with the loss both together and alone. Third, some families faced upheaval in their family life, which required them to re-create their everyday life. In contrast, others continued with little disruption and change.

\section{Theme one: Weaving the death into the family narrative}

Families strived to make meaning of the death through the processes of weaving the death into their family narrative. This process involved constructing a positive family story of "a good death", highlighting the uniqueness of the death compared to other existential family moments, and reflecting on the changes in their multigenerational family configurations.

\section{Storytelling: "It was a good death"}

Families' interactively constructed a story of a "good death". They understood their close other's death as "good" because it had happened late in life and peaceful, as Keira, a 
daughter, noted: "She simply fell asleep. (...) From that point; if it had to happen it could not have been better" (Fisher family). For most, the death occurred after a period of time that not only enabled them to feel prepared but also to fulfil their close other's preferences for the place of death. However, in some families, members lived with differing perceptions and lingering doubts about, for instance, the expectedness or the peacefulness of the death, as Ona, a widow, explained: "It was too bad that I did not get to the hospital in time. (...) I would have liked to know how he died, if he had suffocated?" (Gibson family). Gerard, a son, felt bad about not having been able to fulfil his mother's wish to die at home. Yet he created a positive meaning in that he found that "she probably could like let go in [name of respite care]" (Clarke family). Hence, participants derived positive meanings of the death no matter the exact circumstances. Families' interactive storytelling about the death created conciliation about the ways they had worked together during the end-of-life, and had handled the dying as a family, and enabled them to conclude an intense period in their lives in a positive manner.

\section{Comparing-contrasting: "It's such a vulnerable family moment"}

Family participants understood the death of their significant other as more immediate and consuming than previous deaths in or close to the family, as Marlene, a daughter, stressed: "When someone in the family dies, it's totally different" (Ferro family). It left families feeling vulnerable, as Sophie, a daughter said: "I've seen a few people pass away, but it astonishes me how raw you can feel, over how long a time when it's someone so close to you" (Mendes family). The death denoted a drastic moment and disrupted their lives similar to other extraordinary family moments, such as becoming a parent or seeing the children leave home, as the Patterson sisters explained:

Uma: You say this when you get children, right? Everything's somewhat relative. And when someone dies, you see things in a different light too. The big happenings, right? Brigitta: That's something you can really say. If you would draw a scale of your life to see where there were turning points. That's one, of course, that's been one.

Comparing-contrasting was one family practice through which participants created a meaning of the death as an existential moment that was alike, yet different from previous 
family situations. As such, families drew on their past experiences of incisive family moments to grasp the vulnerability that the death instilled in their family life.

\section{Generational situating: "It's different for everybody"}

The death brought to light for each generation distinct insights about their own life. For spouses, the prospect of dying moved closer, as Henry, a spouse explained: "You don't see it as hard anymore when you know your time comes. It doesn't get at you anymore; you don't chase it away and you know it's not far away anymore" (Brown family). The second family generation gained new insights about their priorities in life. At the same time, they felt enabled to make choices about their own later and end-of-life. Adult children felt like they had received a last parental lesson about how to die in peace, as Susan, a daughter explained (Ford family):

And the whole dying phase (...) was a very formative experience. To experience (...) this finitude, you know, and all the stupid things we worry about. That's something that I've taken away from it. I mean I have a different way of life now.

The third generation encountered death for the first time. Grandchildren faced an utterly unfamiliar experience during a sensitive time in their lives, during which they had to make important decisions about their future, and struggled with adolescence or young adulthood, as Charlotte, a 17-year old granddaughter said: "I'm more irritable. (...) Someone says something and I'm either completely pissed off or immediately very sad. It may be part of adolescence, but it's become like amplified with grandpa's death" (Graham family). Through the family practice of generational situating, families discerned the differences the death implied across generations.

\section{Theme two: Sharing-not sharing the loss}

Family sharing-not sharing surfaced as an oscillating, paradoxical relational pattern that was continually negotiated. It included knowing-not knowing how others in the family were doing, making decisions about revealing-concealing to other family members, and finding comfort or being burdened by others in the family.

\section{Being together}


Families engaged in various sharing practices. For instance, during festive occasions, families remembered the deceased to honour his or her legacy in their lives through sharing memories, talking about who the deceased was as a person, or making a reference to a typical characteristic. In everyday life, talking and taking note allowed family members to create awareness about each other's well-being and feelings around the loss. For instance, adult children made inferences about their parents' well-being based on the conversations they had, and by observing their behaviours and actions. Sebastian, a son explained: "When I visit her [mother] I basically know right away what kind of week she had because you can eat from the floor" (Ford family). Members found comfort from each other, as one granddaughter noted: "I had people around me. (...) That's why I was not pulled down so much, I was rather comforted: Something is now missing, but the basic bricks are still the same as before. And that has helped me the most" (Graham family). Finding comfort occurred through talking, as Edith, a widow explained: "It calms you when someone says something that you've not thought about. This happened a lot with my three [daughters] (...). I remember thinking: 'Look, you didn't get this idea on your own, it does you good'. It calms you“ (Mendes family). Family members enacted presence during painful and sad moments, as Sophie said: "Standing by each other is unbelievably helpful. When you're feeling alone, then you can go to the other" (Mendes family). To alleviate spouses' aloneness, families spent time with each other. For instance, they took turns to spend Sundays with their widowed member and made an effort to be with their close other as often as they could, particularly during holidays, birthdays, or anniversaries. Families enacted sharing on manifold occasions and manners. However, reaching out was not always possible, and situations of aloneness co-occurred.

\section{Being alone}

Not-sharing arose when family members concealed their emotional upset or consciously refrained from sharing. Spouses in particular encountered daily moments during which no human presence could soothe the pain they felt, as Edith illustrated (Mendes family): 
When I get back to the house and nobody is around. Even when a child is with me, but he's not there (cries). It happens all the time, right. I call out: „I am back!“. Doesn't give me an answer, right? But I call out anyway, just as I used to do it: „I'm back“.

Not-sharing also occurred when family members decided not to reveal their sadness, as Chloé, a granddaughter said (Fisher family):

When Mom's sad she doesn't want to tell me because I'm not sad at that moment. When I'm sad I don't want to tell her. (...) If it's happy things, I will speak to Mom about them. Or if I'm more really upset and then I feel even more sad, then I will speak to Mom because I know that she'd be upset that I'm alone and upset.

In their daily lives, family members made decisions from moment to moment about revealing or concealing based on their mutual concern and affection.

\section{Theme three: Continuing to reconstructing family life}

Two family transition trajectories became manifest in families' description of their lives after the loss. While some families faced considerable challenges within their family, particularly around family interactions and practical caring involvements, others did not.

\section{Continuing: "Not much has changed for us"}

Some families (ID 2, 3, 5, 6) experienced little change in their family lives. For some members within these families, particularly spouses (ID 3, 5, 6), death came as a release after a long, worrisome illness period and / or a constraining marriage, as Ida explained: "It simply hasn't been a shock. (...) Rather, it was a release. (...) l've been once well beyond everything, with my strength, right" (Graham family). While some members within these families deeply missed their close other's presence in their lives, the death did not unravel the established ways of being and doing family. Due to the confining presence that the deceased's disabling physical or mental illness had brought about while still alive, these families had previously re-created their interactions and activities before the death, as Ida continued to explain: "I've been alone long before my husband died because he's been so infinitely far away (...). I've been alone, but not lonely". The death enabled families to address issues that they had not been able to talk about previously, such as the family tensions inherent in caregiving, haunting illness memories, or difficult life situations in the deceased's past. Spouses were well able to manage on their own despite some health 
limitations, which reassured their families, as Ida's daughter Susan noted: "She organized herself a good bit already before. And ... (reflects) very self-sufficient. Yes, and basically (...) she embodied that (...). Well, we don't have to worry, we know she's managing" (Graham family). Families' being and doing underwent little change with the death, and was marked by stability and continuation.

\section{Re-constructing: "We have to figure it out"}

Other families faced upheaval that required them to reconfigure their family lives. They had lost with their close other someone who had welded them together through an anchoring or connecting presence. Families were left with a painful void (ID 7, 9, 10) or upheaval around family interactions (ID 1, 4, 8). For instance, the deceased's absence instilled a dis-balance and required families to re-learn what individuals' concerns and actions stood for, negotiate expectations, and craft new ways of doing family, as the example of the Ford family illustrates. Sebastian, the son, explained:

I have to take over [from the deceased] to a certain extent. (...) You need to learn again to find out those things that really bother her, well, like helping her to balance out. (...) When she is all worked up and you get a list of fifteen things, you don't recognize the five central things anymore, and you wipe the whole thing away. Well, we had to find ourselves (...). It's now that this void comes up in everything, with the balancing, being here for-. (...) That's what's missing, and we try to fill it up a bit.

In addition, these families worried about their widowed member's health or emotional wellbeing. Hence, they intensified, rekindled or created new involvements to enact caring that fitted their new situation. As a consequence, some family members became closer with each other, for instance through the process of looking after their widowed parent, or by spending more time together. Sara said about her relationship with her sister (Ford family):

The closeness came about because my mother had (....) reacted very strongly and (...) we were somehow able to look at the difficult stuff and put it into perspective. (...) We talk about that Kirstin does a lot and I don't, and what that's like when she does a lot and it's never enough. And then we get to this good place where we don't have to change anything.

In the wake of loss, these families had to re-create their family being and doing. While they faced some conflict and a painful void, and had to mutually negotiate relationships, they also took away new insights about their family, and felt assured and confident for their shared 
future, as Louis, a widower explained: "You did see our connection, that [it] was real, right" (Ferro family).

\section{DISCUSSION}

This study revealed that families' bereavement experience involves a world that is shared, and a world that lies apart. Families live with their loss together as they integrate shared meanings into their family narrative, enact community through connecting in daily life, and move together to continue or re-create their family life without the deceased. Yet, life with loss unfolded in diverging ways for individuals of the same family, and involved disconnection during moments in which members did not want to, or could not share. Death happens to "a family", but affects members and generations in unique ways.

Families' research participation created a facilitated space for them to construct meanings of the death through the family practices of storytelling, comparing-contrasting, and generational situating. This study demonstrates that families co-construct their narrative in a way that helps them to find peace with their experience of death (Attig 2001, Kiser et al. 2010, Koenig Kellas \& Trees 2013). Previous research has found that meaning-making of a death or a difficult life event occurs during ordinary family conversations (Nadeau 1998, Koenig Kellas \& Trees 2006, Trees \& Koenig Kellas 2009). Such everyday "family speak" allowed families to interlace "individual threads of meaning" (Nadeau, 1998, p. 148), and, similar to this study, unfolded through telling stories and making analogies. Creating a family story of the death is a public act that reveals the "family in operation" (Langellier \& Peterson 2006) and enables them to come away with a meaningful, shared story which they are able to live by (Rober \& Rosenblatt 2013), even when circumstances were painful (Koop \& Strang 2003, Dumont et al. 2008). This study suggests that families construct death in positive ways to grasp it as an incisive family moment that holds generation-specific ramifications, bringing about existential reflections (Black \& Santanello 2012).

Family sharing-not sharing surfaced as an ambiguous but complementary relational process in bereavement. It suggests that family community and aloneness coexist through the interplay of differing forces that move people together and apart (Hartrick 1995, Baxter 
2004, Parse 2009). The current debate about grieving families may thus overemphasize the importance of open family communication and closeness. This study questions the widespread assumption that family members need to talk about their emotions in order to adapt to their new situation, alleviate their pain, and forego a sense of alienation (Walsh \& McGoldrick 2013). Kissane and colleagues (1996a, 1996b) found that those families who tend to feel close, share their distress, and have no or little conflict experience few adverse individual outcomes and adapt well to their new family situation, in contrast to families who do not speak with each other, feel estranged, have some conflict, or do not share emotions. However, in line with an evolving body of research, this study suggests that not-sharing, expressed as not-talking and concealing emotions may be as vital to families' well-being as is sharing through talking and revealing (Stroebe et al. 2005, Baxter 2006). Such a seemingly contradictory way of living relationships already occurs during end-of-life care. In one study, connecting-disconnecting was the main pattern of intimacy and sexuality in couples' relationships when facing a life-limiting illness (Taylor 2014). In another study, "being me and being us in a family" constituted families' "striving for the optimal way of living close to death" at home (Carlander et al. 2011). The negotiation of talking-not talking and revealingconcealing has also been found in couples' relationship after the death of a child (Hooghe et al. 2011, Hooghe et al. 2012, Bergstraesser et al. 2014). Couples faced their young child's loss by negotiating the closeness they could bear to the pain of loss, and the distance they needed to live with the child's absence. It has been postulated that protectionism is a reason for not-sharing (Nadeau 1998, Moss \& Moss 2014). Confronting and avoiding the loss may thus both be needed to regulate grief (Hooghe et al. 2011, Hooghe et al. 2012). However, those aspects in people's grief experience that entail intense suffering remain utterly unsharable, and are an expression of existential aloneness (Stroebe et al. 2005, Wilkinson 2005).

Later life families seem to either experience continuity or disruption after the death of an older member. Participants' new family situation brought to the fore concerns related to widow/ers' health, ability to manage alone and care needs. The death of a family member 
may increase tensions, and bring about the need to negotiate ambiguous and contradictory feelings and expectations around caring commitments between generations (Luescher \& Pillemer 1998, Ingersoll-Dayton et al. 2003, Ha \& Ingersoll-Dayton 2008). At the same time, an augmented sense of closeness, or inner-family strength arose for participants from their ability to share life in different and new ways (Greeff \& Human 1994). Prior research reported that bereaved families felt strengthened in their family "we" (Black \& Santanello 2012). Following the death of a parent, couples may experience greater closeness since they share a new awareness that they had gone through something painful together that enabled them to experience mutual support and understanding (Rosenblatt \& Barner 2006). However, not all families experience changes in their family caring. The extent of continuity experienced by some of the families suggests that later life families may experience a relational loss unrelated and prior to the death, for instance due to emotional distance or chronic illness, which forced them to forge new relationships and caring practices (Schulz et al. 2008, Stajduhar et al. 2010). Hence, death may come as a relief when the work of caregiving or marriages were particularly challenging (Schulz et al. 1997, Pruchno et al. 2009).

Relationships between surviving family members may exhibit remarkable stability, as instrumental and emotional support from children undergoes little change when one parent becomes widowed (Utz et al. 2004, Ha et al. 2006). This was also true for some family participants, yet not for others in this study. The coexistence of both change and continuity in this study somewhat questions the widespread assumption that peoples' taken-for-granted life-world (Attig 2004), or the equilibrium of their system is inherently disrupted by a death (Walsh \& McGoldrick 2004, Walsh \& McGoldrick 2013), as some families in this study experienced little changes in their ways of being and doing family following the death.

\section{Limitations}

The sample was limited to ten multigenerational families who had experienced an age-normative death and who found a common ground to speak about their loss to an outside person. Most family members were spouses and adult daughters, thus, the voices of some family members are only marginally or not represented. Families with non-traditional 
ties, estranged relationships, constrained family resources, or inability to talk about the death could not be recruited into the study. Findings will therefore not capture the full variance of families' bereavement experience. Every effort was undertaken to be reflective of the manners in which the researchers' own positions and pre-understandings have influenced the study. Inevitably however, not all influences could be made conscious. Despito to do so, not every way that the researchers' own perspective shaped the interpretation could axplicit (Gadamer 1975/1989, de Witt \& Ploeg 2006).

\section{CONCLUSIONS}

This study revealed that families hold an inherent capacity to make meaning of an age-normative death and to enact family thereafter. Findings support narrative approaches to bereavement care (Moules \& Streitberger 1997, Hedtke \& Winslade 2004) and family models that emphasize the multivocal and paradoxical nature of family health (Baxter \& Montgomery 1996, Doane \& Varcoe 2005, Parse 2009). Nurses working with bereaved families should first, assess whether families have a need for follow-up care; second, provide primary bereavement care that entails an opportunity for families to ask questions, talk about the end-of-life and dying itself, and receive information; and third, create access to specialist bereavement care as needed (National Institute for Clinical Excellence 2004, Agnew et al. 2010). In so doing, they can invite storytelling to facilitate meaning-making. "Remembering conversations" create an opportunity to shape and re-shape meanings with others (Hedtke 2014). It is important that nurses appreciate the diversity in families' loss experiences and are aware that families differ considerably in the change they experience after a family death. They should recognize that there are moments that cannot be shared, and feelings that persons choose not to divulge. Taking a stance of non-partiality, and without a pre-set agenda for solutions, they can create a space for families to talk about their needs, hopes, and concerns for the future. Nurses may explore with individuals and families how notsharing might be helpful, and how sharing may be comforting (Moules et al. 2007, Hooghe 2012, Kissane \& Dumont 2014). When nurses attend to families' abilities to share, and thematise their adversities or choices to not share, they can strengthen family relationships 
through increasing family members' mutual understanding and respect. Hence, relationshipfocused, health-promoting family interventions that aim to strengthen family relations and to build skills in communicating, working with differences, and creating viable solutions to concrete problems may be most suited to support bereaved families (Martire 2005, Chesla 2010, Thirsk \& Moules 2013, Rumbold \& Aoun 2014).

As one of only a few family bereavement studies whose methodology capture the interactive nature of families' experience, this study's interpretive potential lies in its capacity to enlighten clinicians in their understanding of families' bereavement situations in later life. Further research into diverse families and family health and response patterns is necessary. Longitudinal designs and the inclusion of more than one member allow for a better understanding of how family bereavement unfolds over time. Further inquiry is needed into how families' needs are best assessed, and which families in which circumstances experience an additional burden and suffer more because they lack professional attention. When evaluating family bereavement interventions, it is important to capture the oscillating, paradoxical family processes and avoid privileging one indicator over others, such as closeness, affection, or emotional disclosure. Research should also attend to the intervention processes to render visible the mechanism through which family well-being is achieved.

Funding Statement: This research received no specific grant from any funding agency in the public, commercial, or not-for-profit sectors.

Conflict of Interest Statement: No conflict of interest. 


\section{REFERENCES}

Agnew, A., Manktelow, R., Taylor, B. \& Jones, L. (2010) Bereavement needs assessment in specialist palliative care: A review of the literature. Palliative Medicine, 24(1), 46-59.

Attig, T. (2001) Relearning the world: Making and finding meaning. In Meaning reconstruction and the experience of loss(Neimeyer, R. A. ed. American Psychological Association, Washington, D.C., pp. 33-53.

Attig, T. (2004) Meanings of death seen through the lens of grieving. Death Studies, 28(4), $341-360$.

Baxter, L.A. (2004) Relationships as dialogue. Personal Relationships, 11, 1-22.

Baxter, L.A. (2006) Relational dialectics theory: Multivocal dialogues of family communication. In Engaging theories in family communication: Multiple perspectives(Braithwaite, D. O. and Baxter, L. A. eds.) Sage, Thousand Oaks, CA, pp. $130-145$.

Baxter, L.A. \& Montgomery, B.M. (1996) Relating: dialogues and dialectics, The Guilford Press, New York, NY.

Bell, L., Paul, D., Tribble, D.S.-C. \& Goulet, C. (2000) Strategies to elicit and analyze relational family data. Journal of Family Nursing, 6(4), 380-399.

Benner, P. (1994) The tradition and skill of interpretive phenomenology in studying health, illness and caring practices. In Interpretive phenomenology: Embodiment, caring and ethics in health and illness(Benner, P. ed. Sage, Thousand Oaks, pp. 99-127.

Berger, R. \& Weiss, T. (2009) The posttraumatic growth model: An expansion to the family system. Traumatology, 15(1), 63-74.

Bergstraesser, E., Inglin, S., Hornung, R. \& Landolt, M.A. (2014) Dyadic coping of parents after the death of a child. Death Studies, 39(3), 128-138.

Black, H.K. \& Santanello, H.R. (2012) The salience of family worldview in mourning an elderly husband and father. The Gerontologist, 52(4), 472-483.

Black, H.K., Santanello, H.R. \& Rubinstein, R.L. (2014) A pragmatic belief system in family meaning-making after death. Death Studies, 38(8), 522-530. 
Bonanno, G.A., Wortman, C.B., Lehman, D.R., Tweed, R.G., Haring, M., Sonnega, J., Carr, D. \& Nesse, R.M. (2002) Resilience to loss and chronic grief: A prospective study from preloss to 18-months postloss. Journal of Personality and Social Psychology, 83(5), 1150-1164.

Brazil, K., Bédard, M. \& Willison, K. (2003) Bereavement adjustment and support among caregivers. Journal of Mental Health \& Aging, 9(3), 193-204.

Carlander, I., Ternestedt, B., Sahlberg-Blom, E., Hellström, I. \& Sandberg, J. (2011) Being me and being us in a family living close to death at home. Qualitative Health Research, 21(5), 683-695.

Carr, D., Nesse, R.M. \& Wortman, C.B. (eds.) (2006) Spousal bereavement in late life, Springer, New York.

Chesla, C.A. (1995) Hermeneutic phenomenology: An approach to understanding families. Journal of Family Nursing, 1(1), 63-78.

Chesla, C.A. (2010) Do family interventions improve health? Journal of Family Nursing, 16(4), 355-377.

de Witt, L. \& Ploeg, J. (2006) Critical appraisal of rigour in interpretive phenomenological nursing research. Journal of Advanced Nursing, 55(2), 215-29.

Doane, G.H. \& Varcoe, C. (2005) Family nursing as relational inquiry: Developing healthpromoting practice, Lippincott Williams \& Wilkins, Philadelphia.

Dumont, I., Dumont, S. \& Mongeau, S. (2008) End-of-life care and the grieving process: Family caregivers who have experienced the loss of a terminal-phase cancer patient. Qualitative Health Research, 18(8), 1049-1061.

Gadamer, H.G. (1975/1989) Truth and method, Continuum, London.

Geanellos, R. (1998a) Hermeneutic philosophy. Part I: Implications of its use as methodology in interpretive nursing research. Nursing Inquiry, 5(3), 154-63.

Geanellos, R. (1998b) Hermeneutic philosophy. Part II: A nursing research example of the hermeneutic imperative to address forestructures / pre-understandings. Nursing Inquiry, 5, 283-247. 
Gilbert, K.R. (1996) "We've had the same loss, why don't we have the same grief?" Loss and differential grief in families. Death Studies, 20(3), 269-283.

Greeff, A.P. \& Human, B. (1994) Resilience in families in which a parent has died. The American Journal of Family Therapy, 32(1), 27-42.

Ha, J. (2008) Changes in support from confidants, children, and friends following widowhood. Journal of Marriage and Family, 70(2), 306-318.

Ha, J., Carr, D., Utz, R.L. \& Nesse, R. (2006) Older adults' perceptions of intergenerational support after widowhood: How do men and women differ? Journal of Family Issues, 27(1), 3-30.

Ha, J. \& Ingersoll-Dayton, B. (2008) The effect of widowhood on intergenerational ambivalence. Journals of Gerontology Series B: Psychological Sciences \& Social Sciences, 63B(1), S49-58.

Hartrick, G.A. (1995) Part 1: Transforming family nursing theory: From mechanicism to contextualism. Journal of Family Nursing, 1(2), 134-147.

Hayslip, B. \& Page, K.S. (2013) Family characteristics and dynamics: A systems approach to grief. Family Science, 4(1), 50-58.

Hedtke, L. (2014) Creating stories of hope: A narrative approach to illness, death and grief. Australian \& New Zealand Journal of Family Therapy, 35(1), 4-19.

Hedtke, L. \& Winslade, J. (2004) Re-membering lives: Conversations with the dying and the bereaved, Baywood Publishing Comany, Amityville, NY.

Heidegger, M. (1926/2001) Sein und Zeit, Max Niemeyer Tübingen.

Hooghe, A. (2012) Talking about talking with couples and families. In Techniques of grief therapy: Creative practices for counseling the bereaved(Neimeyer, R. A. ed. Taylor \& Francis, New York, pp. 323-325.

Hooghe, A., Neimeyer, R.A. \& Rober, P. (2011) The complexity of couple communication in bereavement: An illustrative case study. Death Studies, 35(10), 905-24. 
Hooghe, A., Neimeyer, R.A. \& Rober, P. (2012) "Cycling around an emotional core of sadness": Emotion regulation in a couple after the loss of a child. Qualitative Health Research, 22(9), 1220-1231.

Hudson, P. (2013) Improving support for carers: Key implications for research, policy, and practice. Palliative Medicine, 27(7), 581-582.

Ingersoll-Dayton, B., Neal, M.B., Ha, J. \& Hammer, L.B. (2003) Redressing inequality in parent care among siblings. Journal of Marriage and Family, 65(1), 201-212.

Kiser, L.J., Baumgardner, B. \& Dorado, J. (2010) Who are we, but for the stories we tell: Family stories and healing. Psychological Trauma: Theory, Research, Practice, and Policy, 2(3), 243-249.

Kissane, D.W., Bloch, S., Dowe, D.L., Snyder, R.D., Onghena, P., McKenzie, D.P. \& Wallace, C.S. (1996a) The Melbourne Family Grief Study I: Perceptions of family functioning in bereavement. American Journal of Psychiatry, 153(5), 650-658.

Kissane, D.W., Bloch, S. \& McKenzie, D. (1997) Family coping and bereavement. Palliative Medicine, 11, 191-201.

Kissane, D.W., Bloch, S., Onghena, P., McKenzie, D.P., Snyder, R.D. \& Dowe, D.L. (1996b) The Melbourne Family Grief Study, II: Psychosocial morbidity and grief in bereaved families. American Journal of Psychiatry, 153(5), 659-666.

Kissane, D.W. \& Dumont, I. (2014) Therapist techniques in family work. In Bereavement care for families(Kissane, D. W. and Parnes, F. eds.) Routledge, New York, pp. 92-106.

Koenig Kellas, J. \& Trees, A.R. (2006) Finding meaning in difficult family experiences: Sensemaking and interaction processes during joint family storytelling. Journal of Family Communication, 6, 49-76.

Koenig Kellas, J. \& Trees, A.R. (2013) Family stories and storytelling: Windows into the family soul. In The Routledge handbook of family communication(Vangelisti, A. L. ed. Taylor and Francis, New York, pp. 391406. 
Koop, P.M. \& Strang, V.R. (2003) The bereavement experience following home-based family caregiving for persons with advanced cancer. Clinical Nursing Research, 12(2), 127144.

Lalive d'Epinay, C., Cavalli, S. \& Guillet, L.A. (2009) Bereavement in very old age: Impact on health and relationships of the loss of a spouse, a child, a sibling, or a close friend. Omega: Journal of Death and Dying, 60(4), 301-25.

Langellier, K.M. \& Peterson, E.E. (2006) Narrative performance theory: Telling stories, doing family. In Engaging theories in family communication: Multiple perspectives(Braithwaite, D. O. and Baxter, L. A. eds.) Sage, Thousand Oaks, CA, pp. 99-114.

Luescher, K. \& Pillemer, K. (1998) Intergenerational ambivalence: A new approach to the study of parent-child relations in later life. Journal of Marriage and Family, 60, 413425.

Martire, L.M. (2005) The "relative" efficacy of involving family in psychosocial interventions for chornic illness: Are there added benefits to patients and family members? Family, Systems \& Health, 23(3), 312-328.

Moss, M.S. \& Moss, S.Z. (2014) Widowhood in old age: Viewed in a family context. Journal of Aging Studies, 29, 98-106.

Moules, N.J., Simonson, K., Fleiszer, A.R., Prins, M. \& Glasgow, B. (2007) The soul of sorrow work: Grief and therapeutic interventions with families. Journal of Family Nursing, 13(1), 117-41.

Moules, N.J. \& Streitberger, S. (1997) Stories of suffering; stories of strength: Narrative influences in family nursing. Journal of Family Nursing, 3(4), 365-377.

Nadeau, J.W. (1998) Families making sense of death, Sage, Thousand Oaks, CA.

Nadeau, J.W. (2001) Meaning-making in family bereavement: A family systems approach. In Handbook of bereavement reserach: Consequences, coping, and care(Stroebe, M. S., Hansson, R. O., Stroebe, W. and Schut, H. eds.) American Psychological Association, Washington, DC, pp. 329-347. 
Nadeau, J.W. (2008) Meaning-making in bereaved families: Assessment, intervention, and future research. In Handbook of bereavement research and practice: Advances in theory and intervention(Stroebe, M. S., Robert, O. H., Schut, H. and Stroebe, W. eds.) American Psychological Association, Washington, DC, pp. 511-530.

Naef, R., Ward, R., Mahrer-Imhof, R. \& Grande, G. (2013) Characteristics of the bereavement experience of older persons after spousal loss: An integrative review. International Journal of Nursing Studies, 50, 1108-1121.

National Institute for Clinical Excellence (2004) Guidance on cancer services: Improving supportive and palliative care for adults with cancer. The manual. NICE: National Institute for Clinical Excellence, London.

Neimeyer, R.A. (2012) Presence, process, and procedure: A relational frame for technical proficiency in grief therapy. In Techniques of grief therapy: Creative practices for counseling the bereaved(Neimeyer, R. A. ed. Taylor \& Francis, New York, pp. 3-11.

Neimeyer, R.A., Klass, D. \& Dennis, M.R. (2014) A social constructionist account of grief: Loss and the narration of meaning. Death Studies, 38(8), 485-498.

Ott, C.H. \& Lueger, R.J. (2002) Patterns of change in mental health status during the first two years of spousal bereavement. Death Studies, 26, 387-411.

Parse, R.R. (2009) The humanbecoming family model. Nursing Science Quarterly, 22, 305309.

Plager, K.A. (1994) Hermeneutic phenomenology: A methodology for family health and health promotion study in nursing. In Interpretive phenomenology: Embodiment, caring and ethics in health and illness(Benner, P. ed. Sage, Thousand Oaks, pp. 6583.

Powers, S., Bisconti, T.L. \& Bergman, C.S. (2014) Trajectories of social support and wellbeing across the first two years of widowhood. Death Studies, 38(8), 499-509.

Pruchno, R.A., Cartwright, F.P. \& Wilson-Genderson, M. (2009) Effects of marital closeness on the transition from caregiving to widowhood. Aging in Mental Health, 13(6), 80817. 
Rempel, G.R., Neufeld, A. \& Kushner, K.E. (2007) Interactive use of genograms and ecomaps in family caregiving research. Journal of Family Nursing, 13(4), 403-419.

Rober, P. \& Rosenblatt, P.C. (2013) Selective disclosure in a first conversation about a family death in James Agee's novel "A death in the family". Death Studies, 37(2), 172-194.

Rosenblatt, P.C. (1995) Ethics of qualitative interviewing with grieving families. Death Studies, 19(2), 139 - 155.

Rosenblatt, P.C. \& Barner, J.R. (2006) The dance of closeness-distance in couple relationships after the death of a parent. Omega: Journal of Death \& Dying, 53(4), 277-293.

Rumbold, B. \& Aoun, S.M. (2014) Bereavement and palliative care: A public health perspective. Progress in Palliative Care, 22(2), 131-135.

Santos, H.P.O., Black, A.M. \& Sandelowski, M. (2015) Timing of translation in crosslanguage qualitative research. Qualitative Health Research, 25(1), 134-144.

Schulz, R., Beach, S.R., Lind, B., Martire, L.M., Zdaniuk, B., Hirsch, C., Jackson, S. \& Burton, L. (2001) Involvement in caregiving and adjustment to death of a spouse: Findings from the caregiver health effects study. JAMA: Journal of the American Medical Association, 285(24), 3123-9.

Schulz, R., Boerner, K. \& Hebert, R.S. (2008) Caregiving and bereavement. In Handbook of bereavement research and practice: Advances in theory and intervention(Stroebe, M. S., Robert, O. H., Schut, H. and Stroebe, W. eds.) American Psychological Association, Washington DC., pp. 265-285.

Schulz, R., Newsom, J.T., Fleissner, K., Decamp, A.R. \& Nieboer, A.P. (1997) The effects of bereavement after family caregiving. Aging \& Mental Health, 1(3), 269-282.

Shapiro, E.R. (2001) Grief in interpersonal perspective: Theories and their implications. In Handbook of bereavement reserach: Consequences, coping, and care(Stroebe, M. S., Hansson, R. O., Stroebe, W. and Schut, H. eds.) American Psychological Association, Washington, DC, pp. 301-327. 
Smith, J.A. (2007) Hermeneutics, human sciences and health: Linking theory and practice. International Journal of Qualitative Studies on Health and Well-being, 2(3-11).

Smith, J.A., Flowers, R. \& Larkin, M. (2009) Interpretive phenomenological analysis: Theory, method and research, Sage, London, UK.

Spahni, S., Morselli, D., Perrig-Chiello, P. \& Bennett, K.M. (2015) Patterns of Psychological Adaptation to Spousal Bereavement in Old Age. Gerontology, 61(5), 456-468.

Spichiger, E. \& Prakke, H. (2003) Interpretive phenomenology: A research method for nursing [German]. Pflege, 16(3), 128-134.

Stajduhar, K.I., Martin, W. \& Cairns, M. (2010) What makes grief difficult? Perspectives from bereaved family caregivers and healthcare providers of advanced cancer patients. Palliative \& Supportive Care, 8(3), 277-89.

Stroebe, W., Schut, H. \& Stroebe, M.S. (2005) Grief work, disclosure, and counseling: Do they help the bereaved? Clinical Psychological Review, 25, 395-414.

Taylor, B. (2014) Experiences of sexuality and intimacy in terminal illness: A phenomenological study. Palliative Medicine, 28(5), 438-477.

Taylor, B. \& de Vocht, H. (2011) Interviewing separately or as couples? Considerations of authenticity of method. Qualitative Health Research, 21(11), 1576-1587.

Thirsk, L.M. \& Moules, N.J. (2012) Considerations for grief interventions: Eras of witnessing with families. Omega: Journal of Death \& Dying, 65(2), 107-124.

Thirsk, L.M. \& Moules, N.J. (2013) "I can just be me": Advanced practice nursing with families experiencing grief. Journal of Family Nursing, 19(1), 74-98.

Thomas, K., Hudson, P., Trauer, T., Remedios, C. \& Clarke, D. (2014) Risk factors for developing prolonged grief during bereavement in family carers of cancer patients in palliative care: a longitudinal study. Journal of Pain \& Symptom Management, 47(3), $531-541$.

Traylor, E.S., Hayslip, B., Kaminski, P.L. \& York, C. (2003) Relationship between grief and family system characteristics: A cross lagged longitudinal analysis. Death Studies, 27(7), $575-601$. 
Trees, A.R. \& Koenig Kellas, J. (2009) Telling tales: Enacting family relationships in joint storytelling about difficult family experiences. Western Journal of Communication, 73(1), 91-111.

Utz, R.L., Reidy, E.B., Carr, D., Nesse, R. \& Wortman, C.B. (2004) The daily consequences of widowhood. Journal of Family Issues, 25(5), 683-712.

van Manen, M. (1990) Researching lived experience: Human science for an action sensitive pedagogy, State Univesity of New York Press, London.

Walsh, F. \& McGoldrick, M. (2004) Loss and the family: A system perspective. In Living beyond loss: Death in the family(Walsh, F. and McGoldrick, M. eds.) W.W. Norton \& Co, New York, pp. 3-26.

Walsh, F. \& McGoldrick, M. (2013) Bereavement: A family life cycle perspective. Family Science, 4(1), 20-27.

Whittemore, R., Chase, S.K. \& Mandle, C.L. (2001) Validity in qualitative research. Qualitative Health Research, 11(4), 522-537.

Wilkinson, I. (2005) Suffering: A sociological introduction, Polity Press, Cambridge. 
Table 1: Participant characteristics

\begin{tabular}{|c|c|}
\hline Families & $n=10$ \\
\hline No of participating members mean (range) & $3(2-4)$ \\
\hline $\begin{array}{l}\text { Family composition } \mathrm{n}(\%) \\
\text { Spouse, adult child(ren) } \\
\text { Spouse, adult child, grandchild(ren) } \\
\text { Spouse, adult child, sister / brother-in-law }\end{array}$ & $\begin{array}{l}6(60) \\
2(20) \\
2(20)\end{array}$ \\
\hline Age of the deceased mean (range) & $81(76-86)$ \\
\hline $\begin{array}{l}\text { Place of death } \mathrm{n}(\%) \\
\quad \text { Home } \\
\text {... Hospital } \\
\text {...Respite care }\end{array}$ & $\begin{array}{l}5(50) \\
3(3) \\
2(20)\end{array}$ \\
\hline $\begin{array}{l}\text { Cause of death } \mathrm{n}(\%) \\
\quad \text { Cancer } \\
\text {...Chronic lung disease } \\
\text {... Heart failure } \\
\text {...Acute infection } \\
\text { Alzheimer's disease }\end{array}$ & $\begin{array}{l}4(40) \\
2(20) \\
2(20) \\
1(10) \\
1(10)\end{array}$ \\
\hline Professional home care before the death $\mathrm{n}(\%)$ & $8(80)$ \\
\hline Family members & $\mathrm{n}=30$ \\
\hline $\begin{array}{l}\text { Relationship to deceased } \mathrm{n}(\%) \\
\text { Spouse } \\
\text { Adult child } \\
\text { Grandchild } \\
\text { Brother or sister-in-law }\end{array}$ & $\begin{array}{r}10(33.3) \\
14(46.7) \\
3(10.0) \\
3(10.0)\end{array}$ \\
\hline Age mean (range) & $60.4(17-88)$ \\
\hline Female $\mathrm{n}(\%)$ & $23(76.7)$ \\
\hline $\begin{array}{l}\text { Marital status } \mathrm{n}(\%) \\
\text { married / partnership } \\
\text { widowed (spouses only) } \\
\text { separated / divorced / single }\end{array}$ & $\begin{array}{r}17(56.7) \\
10(33.3) \\
3(10.0)\end{array}$ \\
\hline $\begin{array}{l}\text { Number of children } n(\%) \\
\geq 3 \text { children } \\
1-2 \text { children } \\
\text { no children (grandchildren only) }\end{array}$ & $\begin{array}{r}10(33.3) \\
17(56.7) \\
3(10.0)\end{array}$ \\
\hline $\begin{array}{l}\text { Education in years } n(\%)(n=29) \\
\leq 9 \text { years } \\
10-12 \text { years } \\
\geq 13-16 \text { years }\end{array}$ & $\begin{array}{r}11(37.9) \\
8(27.6) \\
10(34.5)\end{array}$ \\
\hline $\begin{array}{l}\text { Ability to manage with monthly income }(\%)(n=29) \\
\text { Easy to manage } \\
\text { Rather easy to manage } \\
\text { Sometimes difficult to manage } \\
\text { Difficult to manage }\end{array}$ & $\begin{array}{r}14(48) \\
10(35) \\
5(17) \\
0(00)\end{array}$ \\
\hline
\end{tabular}




\section{Table 2: Family participants}

\begin{tabular}{|c|c|c|c|c|c|c|}
\hline Family* & Family members* & Relationship to deceased & Caregiving situation & Age at, cause \& place of death* & Interviews & Duration \\
\hline $\begin{array}{l}\text { Clarke } \\
(01)\end{array}$ & $\begin{array}{l}\text { George (88y), Gerard (57y), } \\
\text { Barbara (54y) }\end{array}$ & Widower, son, daughter & $\begin{array}{l}\text { End of life family and home } \\
\text { nursing care for } 2 \text { months }\end{array}$ & $\begin{array}{l}\text { Bertha }(87 y) \text { died of cancer in respite } \\
\text { care }\end{array}$ & 3 family & $4: 11 \mathrm{~h}$ \\
\hline $\begin{array}{l}\text { Brown } \\
(02)\end{array}$ & Henry (84y), Victoria (59y) & Widower, daughter & $\begin{array}{l}\text { Family and home nursing care } \\
\text { for } 4.5 \text { years }\end{array}$ & $\begin{array}{l}\text { Molly }(84 y) \text { died of Alzheimer's } \\
\text { disease in respite care }\end{array}$ & $\begin{array}{l}2 \text { family } \\
2 \text { individual }\end{array}$ & $6: 14 \mathrm{~h}$ \\
\hline $\begin{array}{l}\text { Ferro } \\
(10)\end{array}$ & $\begin{array}{l}\text { Louis }(81 y), \text { Marlene }(48 y) \text {, } \\
\text { Harry }(80 y), \text { Helen }(73 y)\end{array}$ & $\begin{array}{l}\text { Widower, daughter, brother } \\
\& \text { sister-in-law }\end{array}$ & - & $\begin{array}{l}\text { Ella (76) died of sudden cardiac arrest } \\
\text { at home }\end{array}$ & $\begin{array}{l}3 \text { family } \\
1 \text { individual }\end{array}$ & $4: 40 \mathrm{~h}$ \\
\hline $\begin{array}{l}\text { Fisher } \\
(05)\end{array}$ & $\begin{array}{l}\text { Marcus (83), Keira (54y), } \\
\text { Chloé (18y) }\end{array}$ & $\begin{array}{l}\text { Widower, daughter, grand- } \\
\text { daughter }\end{array}$ & $\begin{array}{l}\text { Family and home nursing care } \\
\text { for about } 2 \text { years }\end{array}$ & Elizabeth (82y) died of COPD at home & $\begin{array}{l}2 \text { family } \\
1 \text { individual }\end{array}$ & $5: 11 \mathrm{~h}$ \\
\hline $\begin{array}{l}\text { Ford } \\
(08)\end{array}$ & $\begin{array}{l}\text { Alice (78y), Sebastian (49y), } \\
\text { Kirstin (50y), Susan (52y) }\end{array}$ & Widow, son, 2 daughters & $\begin{array}{l}\text { End of life family and palliative } \\
\text { home care for } 3 \text { weeks }\end{array}$ & $\begin{array}{l}\text { Alfie }(80 y) \text { died of prostate cancer at } \\
\text { home }\end{array}$ & $\begin{array}{l}1 \text { family } \\
4 \text { individual }\end{array}$ & $7: 58 \mathrm{~h}$ \\
\hline $\begin{array}{l}\text { Gibson } \\
(03)\end{array}$ & Ona (81y), Emma (61y) & Widow, daughter & $\begin{array}{l}\text { Family and oncology home care } \\
\text { for } 2 \text { years }\end{array}$ & $\begin{array}{l}\text { Arthur (81y) died of lung cancer in } \\
\text { hospital }\end{array}$ & $\begin{array}{l}1 \text { family } \\
3 \text { individual }\end{array}$ & $3: 49 \mathrm{~h}$ \\
\hline $\begin{array}{l}\text { Graham } \\
(06)\end{array}$ & $\begin{array}{l}\text { Ida (78y), Susan (48y), Nina } \\
(24 y), \text { Charlotte (17y) }\end{array}$ & $\begin{array}{l}\text { Widow, daughter, } 2 \text { grand- } \\
\text { daughters }\end{array}$ & - & $\begin{array}{l}\text { Joseph }(78 y) \text { died of heart failure at } \\
\text { home }\end{array}$ & $\begin{array}{l}3 \text { family } \\
1 \text { individual }\end{array}$ & $6: 13 \mathrm{~h}$ \\
\hline $\begin{array}{l}\text { Mendes } \\
(09)\end{array}$ & Edith (75y), Sophie (46y) & Widow, daughter & $\begin{array}{l}\text { End of life family and palliative } \\
\text { home care for } 2 \text { months }\end{array}$ & $\begin{array}{l}\text { Carlos (81y) died of prostate cancer at } \\
\text { home }\end{array}$ & 2 family & $2: 39 h$ \\
\hline $\begin{array}{l}\text { Patterso } \\
\mathrm{n}(07)\end{array}$ & $\begin{array}{l}\text { Isabelle (81y), Brigitta (49y), } \\
\text { Uma (42y) }\end{array}$ & Widow, 2 daughters & Wound home care & $\begin{array}{l}\text { Paul }(81 y) \text { died of an acute infection in } \\
\text { hospital }\end{array}$ & $\begin{array}{l}2 \text { family } \\
1 \text { individual }\end{array}$ & $4: 16 h$ \\
\hline $\begin{array}{l}\text { Richard } \\
(04)\end{array}$ & $\begin{array}{l}\text { Rosa (75y), Maria (77y), } \\
\text { Stella (50y) }\end{array}$ & $\begin{array}{l}\text { Widow, sister-in-law, } \\
\text { daughter }\end{array}$ & $\begin{array}{l}\text { Family and home nursing care } \\
\text { for } 2 \text { years }\end{array}$ & James (80y) died of COPD in hospital & $\begin{array}{l}2 \text { family } \\
3 \text { individual }\end{array}$ & $5: 37 \mathrm{~h}$ \\
\hline
\end{tabular}

* Code names were used throughout the study. 
1

2

3

4

5

6

7

10

11

12

13

14

15

16

17

18

19

20

21

22

23

24

25

26

27

28

29

30

31

32

33

34

35

36

37

38

39

40

41

42

43

44

45

46

47

48

49

50

51

52

53

54

55

56

57

58

59

60

Table 3: Thematic overview

\begin{tabular}{ll}
\hline Main themes & Family practices (sub-themes) \\
\hline Weaving the death into the family narrative & Storytelling \\
& Comparing-contrasting \\
& Generational situating \\
\hline Sharing-not sharing the loss & Being together \\
& Being alone \\
\hline Continuing to reconstructing family life & Continuing \\
& Re-constructing \\
\hline
\end{tabular}




\section{Impact Statement}

This study takes a relational approach to understand families' interactive experience when they are faced with the death of an older member. Since grief has predominantly been studied as an intrapersonal process from the perspective of bereaved spouses or carers, families' situation and interactions following a loss late in life is poorly understood. This qualitative study informs family-centred, relationship-focus end-of-life and bereavement care across a variety of settings and is of particular interest to nurses, but holds relevance to a broad range of health professionals who are working with older persons, carers, and families in later life. 